\title{
Pengaruh Kepemilikan Manajerial, Leverage dan CSR terhadap Nilai Perusahaan, Studi Kasus Perusahaan Jasa di Indonesia

\author{
Wastam wahyu hidayat, ${ }^{1, T r i a n a}$ Yuniati $^{2}$, Ery Teguh Prasetyo ${ }^{3}$, Cahyadi Husadha4 \\ Fakultas Ekonomi dan Bisnis, Universitas Bhayangkara Jakarta Raya ${ }^{1,2,3,4}$ \\ Wastam.wahyu@dsn.Ubharajaya.ac.id.triana.yuniati@dsn.ubharajaya.ac.id. \\ Ery.teguh@dsn.ubharajaya.ac.id. cahyadi.husadha@dsn.ubhara.jaya.ac.id
}

\begin{abstract}
ABSTRAK
Tujuan dari penelitian ini adalah untuk mengetahui pengaruh kepemilikan manajerial, Leverage, dan Corporate Social Responsibility terhadap Nilai Perusahaan. Sampel yang digunakan adalah perusahaan jasa yang terdaftar di Bursa Efek Indonesia dengan jumlah 13 perusahaan dan tahun penelitian selama lima tahun. Analisis yang digunakan pada penelitian ini adalah Regresi berganda dengan SPSS-22. Sedangkan hasil penelitian adalah secara parsial menunjukan bahwa kepemilikan manajerial tidak berpengaruh secara signifikan terhadap nilai perusahaan. Leverage berpengaruh negative dan signifikan terhadap nilai perusahaan. Corporate Social Responsibility berpengaruh positif dan signifikan terhadap nilai perusahaan. Sedangkan secara simultan kepemilikan manajerial, leverage, dan corporate social responsibility terhadap nilai perusahaan berpengaruh positif dan signifikan terhadap nilai perusahaan.
\end{abstract}

Kata Kunci : Kepemilikan Manajerial, DAR, CSR, Tobin's Q

\begin{abstract}
The purpose of this study is to determine the influence of managerial ownership, Leverage, and Corporate Social Responsibility on the Company's Values. The samples used are service companies listed on the Indonesia Stock Exchange with a total of 13 companies and years of research for five years. The analysis used in this study is multiple regressions with SPSS-22. While the results of the study are partially showing that managerial ownership has no significant effect on the value of the company. Leverage has a negative and significant effect on the value of the company. Corporate Social Responsibility has a positive and significant effect on the value of the company. While simultaneously managerial ownership, leverage, and corporate social responsibility to the value of the company has a positive and significant effect on the value of the company.

Keywords : Managerial Ownership, DAR, CSR, Tobin's Q
\end{abstract}

Diterima: 30 Maret 2021; Direvisi: 6 April 2021; Diterbitkan: 20 April 2021

\section{PENDAHULUAN}

Persaingan usaha yang ada pada saat ini membuat setiap perusahaan perlu menggunakan strategi yang tepat untuk meningkatkan kinerja perusahaan agar dapat mencapai tujuan perusahaan.
Memaksimalkan nilai perusahaan merupakan salah satu tujuan dan strategi agar perusahaan dapat bertahan dalam persaingan. Memaksimalkan nilai perusahaan dapat memberikan kesejahteraan bagi para pemegang saham serta pihak lain yang berhubungan dengan 
perusahaan. Dengan adanya jaminan kesejahteraan bagi para pemegang saham, dapat membuat para pemegang saham tidak ragu untuk tetap berinvestasi dalam perusahaan serta memungkinkan calon investor dari luar untuk berinvestasi. Nilai perusahaan merupakan persepsi investor terhadap tingkat keberhasilan perusahaan, yang sering dikaitkan dengan harga saham (Rahma, 2014) dalam Widyaningsih, (2018).

Dengan meningkatnya harga saham suatu perusahaan, maka akan meningkat pula nilai perusahaan tersebut. Nilai perusahaan juga dapat menjadi salah satu cara untuk mengukur tingkat keberhasilan seorang manajer. Para pemegang saham akan menyerahkan urusan perusahaan kepada seorang manajer karena manajer dianggap ahli dalam bidang tersebut. Dalam pengambilan keputusan, manajer harus bertindak secara efektif dan efisien, hal tersebut guna mempertahankan kelangsungan hidup perusahaan sehingga nilai perusahaan dapat terus meningkat.

Kepemilikan manajerial dapat menjadi salah satu cara dalam mengurangi konflik antara manajer dengan para pemegang saham. Manajer yang memiliki saham perusahaan memiliki peran sebagai manajer perusahaan dan sebagai pemegang saham. Sedangkan manajer yang tidak memiliki saham perusahaan kemungkinan lebih mementingkan kepentingan pribadinya. Hal tersebut dikuatkan oleh Sudarma dan Darmayanti, (2017) menyatakan bahwa kepemilikan manajerial berpengaruh positif dan signifikan terhadap nilai perusahaan. Namun, dalam penelitian yang dilakukan Puspaningrum, (2017) menyatakan bahwa kepemilikan manajerial berpengaruh positif, dan tidak signifikan terhadap nilai perusahaan.
Selain kepemilikan manajerial, faktor yang dapat mempengaruhi nilai perusahaan adalah leverage. Leverage merupakan penggunaan biaya melalui utang. Pembiayaan melalui utang pada struktur modal merupakan pertimbangan yang penting bagi sebuah perusahaan. Pada umumnya, investor menghindari perusahaan yang memiliki nilai rasio leverage yang tinggi karena semakin tinggi rasio leverage, maka akan semakin tinggi pula risiko yang akan ditanggung khususnya apabila perusahaan tidak dapat memenuhi kewajibannya secara tepat waktu. Para kreditor juga lebih menyukai rasio utang yang lebih rendah, karena semakin randah utang artinya semakin tinggi tingkat pendanaan perusahaan yang disediakan oleh pemegang saham, sehingga semakin besar perlindungan bagi kreditor atas risiko tidak terbayarnya utang. Dalam mengukur leverage, penelitian ini menggunakan debt to total asset ratio.

Jika sebuah perusahaan ingin menggunakan utang yang cukup besar, diperlukan penjualan yang tinggi agar perusahaan tidak menanggung beban bunga yang lebih tinggi. Beban bunga dapat mengurangi laba bersih, namun diharapkan tingkat pengembalian yang tinggi dengan penggunaan leverage. Tingkat pengembalian yang tinggi menggambarkan bahwa perusahaan mampu menghasilkan laba. Hal ini dapat mempengaruhi nilai pasar atas harga saham perusahaan. Penelitian Sofiamira dan Asandimitra, (2017) menyatakan bahwa leverage berpengaruh negatif signifikan terhadap nilai perusahaan. Namun, Mareta dan Yanti (2019) menyatakan bahwa leverage tidak berpengaruh terhadap nilai perusahaan.

Faktor lain yang dapat mempengaruhi nilai perusahaan adalah kepedulian terhadap lingkungan dan membuat 
munculnya sebuah pengembangan yang disebut dengan Corporate Social Responsibility (CSR). Bagi sebuah perusahaan di Indonesia, CSR bukan lagi plihan melaikan kewajiban yang harus dilakukan oleh perusahaan dalam menjaga dan melestarikan lingkungan sekitar. Hal tersebut diatur dalam Pasal 1 ayat (3), dan Pasal 74 Undang-Undang Nomor 40 tahun 2007 tentang Perseron Terbatas. Penelitian Rahmah, (2016) menyatakan bahwa CSR tidak berpengaruh secara signifikan terhadap nilai perusahaan. Puspaningrum, (2017) menyatakan bahwa CSR memiliki pengaruh negatif dan tidak signifikan terhadap nilai perusahaan. Hasil ini sejalan dengan penelitian yang dilakukan oleh Sudarma dan Damayanti, (2017) yang menyatakan bahwa CSR memiliki pengaruh negatif dan tidak signifikan terhadap nilai perusahaan.

Tujuan penelitian ini adalah memberikan masukan kepada perusahaan jasa bahwa dalam meningkatkan nilai perusahaan terdapat hambatan yang mungkin dihadapi. Hambatan yang sering dihadapi dalam perusahaan adalah agency conflict, yaitu konflik antara manajer dengan para pemegang saham dan juga bagaiamana pimpinan perusahaan melakukan manajemen rasio antara utang dengan Asset sehinnga, rasio ini mampu meningkatkan nilai perusahann, serta bila perusahaan melakukan pengungkapan CSR secara berkelanjutan dalam perusahaan mungkin akan menambah biaya perusahaan atau sebaliknya sehingga berdampak terhadap Nilai Perusahaan.

\section{LANDASAN TEORI}

\section{Kepemilikan Manajerial}

Struktur kepemilikan yang baik dipercaya dapat mempengaruhi jalannya perusahaan yang dapat mempengaruhi kinerja suatu perusahaan. Dilihat dari sudut pandang, struktur kepemilikan terdiri atas pendekatan keagenan dan pendekatan ketidakseimbangan. Pendeketan keagenan menganggap struktur kepemilikan manajerial sebagai suatu instrument atau alat yang digunakan untuk mengurangi konflik keagenan diantara beberapa klaim terhadap sebuah perusahaan. Pendekatan ketidakseimbangan informasi memandang struktur kepemilikan manajerial sebagai suatu cara untuk mengurangi ketidakseimbangan informasi antara insider dan outsider melalui pengungkapan informasi di dalam perusahaan (Subagyo et al, 2018). Sonya Majid (2016) dalam Rezky (2017), menyatakan bahwa kepemilikan manajerial adalah pemegang saham dari pihak manajemen yang secara aktif ikut dalam pengambilan keputusan di dalam perusahaan, misalnya direktur dan komisaris. Pasaribu et al. (2016) dalam rezky (2017) menyatakan bahwa kepemilikan manajerial adalah pemilik/pemegang saham oleh pihak manajemen perusahaan yang secara aktif berperan dalam pengambilan keputusan. Kepemilikan saham oleh manajemen dapat mempengaruhi kinerja manajemen dalam mengoptimalkan perusahaan. Hal ini dapat mempengaruhi jalannya hidup perusahaan. Manajer perusahaan dapat melakukan tugas sebagai delegasi dari pemegang saham dengan mengelola perusahaan sesuai dengan kepentingan para pemegang saham.

\section{Leverage}

Leverage merupakan $\begin{array}{r}\text { tingkat } \\ \text { dalam }\end{array}$
kemampuan perusahaan an an an
menggunakan aktiva atau dana yang
mempunyai beban tetap (hutang atau
saham istimewa) dalam rangka


mewujudkan tujuan perusahaan untuk memaksimalkan kekayaan pemilik perusahaan. Leverage ratio (rasio solvabilitas / rasio utang) merupakan rasio yang digunakan untuk mengukur seberapa besar perusahaan dibiayai dengan hutang. Penggunaan utang yang terlalu tinggi dalam perusahaan dapat memahayakan karena perusahaan akan masuk kategori extreme leverage (utang ekstrim) yaitu keadaan dimana perusahaan akan terjebak dalam utang yang tinggi serta sulit untuk lepas dari beban utang tersebut. Menurut ngadiman, dalam Puspitasari (2014), leverage adalah penggunaan dana dari pihak eksternal berupa hutang untuk membiayai investasi atau asset perusahaan. Penggunaan rasio utang yang dapat dikendalikan oleh perusahaan dapat memberikan manfaat bagi perusahaan. Debt Ratio merupakan rasio utang yang digunakan dalam mengukur perbandingan antara total hutang dengan total aktiva.

\section{Corporate Social Responsibility}

Menurut Kotler dan Lee, "Corporate Social Responsibility is a commitment to improve community well being trough diseretionary business practices and contribution of corporate resource." dalam (Rahmah, 2016) Berdasarkan apa yang diungkapkan Kotler dan Lee tersebut, corporate social responsibility merupakan sesuatu yang dilakukan atas keinginan sendiri dalam upaya meningkatkan kesejahteraan perusahaan dan bukan bagian dari aktivitas perusahaan yang diwajibkan oleh hukum dan perundangundangan.

Sedangkan di Indonesia saat ini, pelaksanaan corporate social responsibility merupakan suatu hal yang wajib dilakukan perusahaan. Salah satu peraturan mengenai corporate social responsibility diatur dalam Pasal 74 Ayat 1 Undang-Undang Nomor 40 tahun 2007 tebtang Perseroan Terbatas "Perseroan yang menjalankan kegiatan usahanya dibidan dan/atau berkaitan dengan sumber daya alam wajib melaksanakan tanggung jawab sosial dan lingkungan.

Menurut Gurvy Kavei dalam Rahmah, (2016), pakar manajemen dari Universitas Manchester, Inggris, menegaskan bahwa setiap perusahan yang mengimplementasikan CSR dalam aktivitas usahanya akan mendapatkan 5 (lima) manfaat utama, yaitu sebagai berikut:

1. Meningkatkan profitabilitas dan kinerja financial yang lebih kokoh, misalnya lewat efisiensi lingkungan,

2. Meningkatkan alat akuntabilitas, assessment, dan komunitas investasi,

3. Mendorong komitmen karyawan karena mereka telah diperhatikan dan dihargai,

4 Menurunkan kerentanan masalah dengan komunitas, dan

5. Mempertinggi reputasi, dan corporate branding.

Sesuai peraturan OJK Nomor 51/POJK.03/2017 tentang Penerapan Keuangan Berkelanjutan Bagi Lembaga Jasa Keuangan, Emiten, dan Perusahaan Publik Pasal 1 ayat 13, Laporan keberlanjutan adalah laporan yang diumumkan kepada masyarakat yang memuat kinerja ekonomi, keuangan, sosial, dan lingkungan hidup suatu Lembaga Jasa Keuangan (LJK), Emiten, dan Perusahaan Publik dalam menjalankan bisnis. Dalam laporan keberlanjutan standar yang digunakan sesuai dengan Global Reporting 
Intiative (GRI). Menurut pedoman GRI, laporan keberlanjutan perlu mencantumkan indeks isi GRI, yang disajikan dalam satu lokasi dan mencakup nomor halaman atas URL untuk semua pengungkapan yang dilaporkan.

Standar GRI merupakan dasar dalam penyusunan laporan keberlanjutan yang dirancang agar tercipta pemahaman yang sama bagi organisasi dan pemangku kepentingan, sehingga informasi atas dampak ekonomi, lingkungan, dan sosial dari berbagai organisasi dapat dikomunikasikan, dipahami, dan diperbandingankan secara global (Ramadani, 2019).Pada tanggal 22 Mei 2013, GRI merilis G4 Guidelines yang efektif hingga tanggal 30 Juni 2018. Pada tanggal 19 Oktober 2016, GRI menerbitkan standar GRI terbaru yang mulai efektif pada tanggal 1 Juli 2018 hingga saat ini. Laporan yang diterbitkan pada atau setelah 1 Juli 2018 diharuskan menggunakan Standar GRI. Jika laporan keberlanjutan yang diterbitkan tidak sesuai dengan Standar GRI, maka laporan tersebut tidak akan dianggap sebagai laporan keberlanjutan berbasis GRI.

\section{Nilai Perusahaan}

Martono dan Harjito (2013) dalam Rahmah (2016) menyatakan bahwa "memaksimalkan nilai perusahaan disebut sebagai memaksimalkan kemakmuran pemegang saham (stakeholder wealth maximation) yang dapat diartikan juga sebagai memaksimumkan harga saham biasa dari perusahaan (maximizing the price of the firm's common stock)".

Nilai perusahaan merupakan sesuatu yang sangat penting bagi perusahaan karena dengan peningkatan nilai perusahaan akan diikuti dengan kenaikan harga saham yang mencerminkan peningkatan kemakmuran pemegang saham. Nilai perusahaan yang sudah go public tercermin dalam harga pasar saham perusahaan, sedangkan perusahaan yang belum go public nilainya terealisasi apabila perusahaan akan dijual (Margaretha, 2014) dalam Rezky (2017).

Umumnya nilai perusahaan dinilai berdasarkan jumlah tenaga kerja dan modal yang diperlukan untuk memproduksi, memasarkan, dan mendistribusikan aset yaitu sebesar biaya penggantian. Dalam pasar modal, perusahaan dinilai berdasarkan laba di masa depan, yang tercermin dari risiko relatif aset yang digunakan perusahaan untuk menghasilkan pendapatan. Formula ini diperkenalkan oleh James Tobin pada tahun 1969. James membangun suatu teori yang disebut Teori $\mathrm{Q}$ Tobin (Tobin's Q theory).

Inti teori ini adalah cara kebijakan moneter mempengaruhi perekonomian melalui pengaruhnya pada penilaian ekuitas. Tobin's Q adalah nilai pasar dari common stocks dan financial liabilities. Tobin's Q merupakan perbandingan nilai pasar perusahaan dengan investasi bersihnya. Jika harga saham meningkat, maka nilai perusahaan juga akan mengalami peningkatan (Fauziah, 2017).

Tobin's Q merupakan gambaran statistik yang berfungsi sebagai proksi dari nilai perusahaan. Nilai Tobin's Q dihasilkan dari penjumlahan nilai pasar saham (market value of all outstanding stock) dan nilai pasar hutang (market value of all debt), dibandingkan dengan nilai seluruh modal yang ditempatkan dalam aktiva produksi (replacement value of all production capacity). Interpretasi nilai 
Tobin's Q menurut Sudiyatno dan Puspitasari (2010), dalam buku Fauziah (2017) sebagai berikut:

1. Tobin's $\mathrm{Q}<1$ menunjukkan bahwa saham dalam kondisi under value. Artinya, manajemen telah gagal dalam mengelola aktiva perusahaan dan memiliki potensi pertumbuhan investasi yang rendah.

2. Tobin's $\mathrm{Q}=1$ menunjukkan bahwa saham dalam kondisi average. Artinya, manajemen stagnan dalam mengelola aktiva dan potensi pertumbuhan investasinya tidak berkemba.

3. Tobin's $\mathrm{Q}>1$ menunjukkan bahwa saham dalam kondisi over value. Artinya, manajemen berhasil dalam mengelola aktiva perusahaan dan memiliki potensi pertumbuhan investasi yang tinggi.

\section{Kerangka Pemikiran}

\section{Pengaruh Kepemilikan Manajemen terhadap Nilai Perusahaan}

Semakin tinggi kepemilikan manajerial diharapkan pihak manajemen akan berusaha semaksimal mungkin dan termotivasi untuk meningkatkan kerja untuk kepentingan para pemegang saham.Menurut,(Pracihara, 2016) bahwa Kepemilikan manajerial adalah persentase kepemilikan saham pada perusahaan oleh pihak manajerial. Manajer yang sekaligus pemegang saham akan berusaha bekerja secara optimal dan tidak hanya mementingkan kepentingannya sendiri.

Manajemen selalu berupaya meningkatkan kinerja dan nilai perusahaan karena dengan meningkatkan kinerja dan nilai perusahaan maka kekayaannya yang dimiliki sebagai pemegang saham akan meningkat, sehingga kesejahteraan pemegang saham akan meningkat pula selain itu kepemilikan manajerial sangat bermanfaat dimana manajer juga ikut ambil bagian dalam kepemilikan saham perusahaan. Manajer kemudian akan berusaha lebih baik untuk meningkatkan nilai perusahaan sehingga ia pun dapat menikmati sebagian keuntungan yang menjadi bagiannya tersebut.

Kepemilikan manajerial merupakan program kebijakan remunerasi guna mengurangi masalah keagenan. Tingkat Kepemilikan Manajerial merupakan kepemilikan atas saham perusahaan yang dimiliki oleh manajemen. Tingkat kepemilikan manajerial ini diukur dengan membagi jumlah saham yang dimiliki oleh pemegang saham pengendali dengan dengan jumlah saham yang beredar.

Menurut,(Christiani \& Herawaty, 2019) bahwa Kepemilikan manajerial dianggap menjadi pihak kontroling yang mampu menghilangkan konflik agensi yang menimbulkan biaya agensi yang tinggi sehingga nilai perusahaan akan naik dengan indikator harga sahamnya naik. Menurut,(Widhaningayu, 2017), Kepemilikan institusional adalah besarnya jumlah saham yang dimiliki institusi dari total saham beredar. Adanya kepemilikan institusional dapat memantau secara professional perkembangan investainya sehingga tingkat pengendalian terhadap manajemen sangat tinggi yang pada akhirnya dapat menekan potensi kecurangan.

H-1. Kepemilikan Manajerial berpengaruh positif terhadap Nilai Perusahaan

\section{Pengaruh Leverage terhadap Nilai Perusahaan}


Leverage merupakan suatu alat penting dalam pengukuran efektivitas penggunaan utang perusahaan. Dengan menggunakan leverage, perusahaan tidak hanya dapat memperoleh keuntungan namun juga dapat mengakibatkan perusahaan mengalami kerugian, karena leverage keuangan berarti perusahaan membebankan risiko kepada pemegang saham sehingga mempengaruhi return Saham.

Menurut, (Prasetyorini, 2013), Konsep leverage ini penting bagi investor dalam membuat pertimbangan penilaian saham. Para investor umumnya cenderung menghindari risiko. Risiko yang timbul dalam penggunaan financial leverage disebut dengan financial risk yaitu risiko tambahan yang dibebankan kepada pemegang saham sebagai hasil penggunaan utang oleh perusahaan. Semakin tinggi leverage, semakin besar risiko keuangannya dan sebaliknya.

Menurut,(Hidayat, 2018), ,Leverage adalah rasio yang digunakan untuk mengukur sejauh mana aktiva perusahaan dibiayai oleh utang, artinya seberapa besar beban utang yang ditanggung perusahaan dibandingkan dengan aktivanya, atau rasio ini untuk mengukur kemampuan perusahaan untuk membayar seluruh kewajibannya baik jangka pendek maupun jangka panjang (total utang/total asset), sedangkan secara prakteknya untuk menutupi kekurangan akan kebutuhan dana, perusahaan memiliki beberapa pilihan sumber dana yang dapat digunakan, salah satu sumber dana yang digunakan adalah modal pinjaman (utang), modal pinjaman relatif tidak terbatas jumlahnya dan memotivasi manajemen untuk bekerja lebih aktif dan kreatif karena dibebani untuk membayar beban kewajibannya dan meningkatkan Nilai Perusahaan.
Menurut,(Kusumayanti \& Astika, 2016), Semakin tinggi tingkat leverage suatu perusahaan, maka semakin besar peluang perusahaan mengalami pailit, sehingga risiko kreditur pun akan meningkat, dan dapat menimbulkan masalah kegenan (LiJu dan Shun-Yu, 2011). Hal ini sesuai dengan pecking order theory, yang menyatakan bahwa perusahaan lebih menyukai pendanaan dengan dana perusahaan sendiri (internal financing) daripada pendanaan dari luar perusahaan (external financing) untuk menjaga agar rasio leverage tidak bertambah tinggi.

\section{H-2. Leverage berpengaruh negatif terhadap Nilai Perusahaan}

\section{Pengaruh Corporate Social Responsibility (CSR) terhadap Nilai Perusahaan}

Menurut,(Fajriana \& Priantinah, 2016), Penerapan CSR tidak lagi dianggap sebagai cost, tetapi investasi perusahaan seiring semakin pentingnya CSR bagi perusahaan. Pelaksanaan CSR telah diatur dalam Undang-Undang No. 25 Tahun 2007 tentang Penanaman Modal dan UU Nomor 40 Tahun 2007 Tentang Perseroan Terbatas (UU PT). Namun, peraturan tersebut belum mampu meningkatkan jumlah perusahaan yang menerapkan CSR. Rendahnya tingkat pelaksanaan dan pengungkapan CSR ini akan menghambat perusahaan dalam hal memperoleh kepercayaan dari investor karena CSR menjadi salah satu hal yang diperhatikan investor ketika akan berinvestasi di sebuah perusahaan.

Menurut,(Nurhayati, Poerwati, \& Kartika, 2019). Perusahaan yang percaya banhwa menyisihkan sebagian dananya untuk melakukan tanggung jawab sosialnya serta melakukan dan mengungkapkan CSR akan dapat meningkatkan nilai perusahaan yang terlihat dari semakin banyaknya 
investor yang menanamkan dananya pada perusahaan tersebut.Menurut,(Triyono \& Setyadi, 2015) CSR merupakan bentuk tanggung jawab perusahaan dalam memperbaiki kesenjangan sosial dan kerusakan lingkungan yang terjadi akibat aktivitas operasional perusahaan. Semakin banyak bentuk pertanggungjawaban yang dilakukan perusahaan terhadap lingkungannya, image perusahaan menjadi meningkat. Investor lebih berminat pada perusahaan yang memiliki citra yang baik di masyarakat karena semakin baiknya citra perusahaan, loyalitas konsumen semakin tinggi sehingga dalam waktu lama penjualan perusahaan akan membaik dan profitabilitas perusahaan juga meningkat. Jika perusahaan berjalan lancar, maka nilai saham perusahaan akan meningkat.

Menurut,(Widhaningayu, 2017), CSR lahir dari desakan masyarakat atas perilaku perusahaan yang biasanya selalu fokus untuk memaksimalkan laba, menyejahterakan para pemegang saham., dan mengabaikan tanggung jawab sosial seperti perusakan lingkungan, eksploitasi sumber daya alam, dan lain sebagainya. Pada intinya, keberadaan perusahaan berdiri secara berseberangan dengan kenyataan kehidupan sosial. Konsep dan praktik CSR saat ini bukan lagi dipandang sebagai suatu cost center, tetapi juga sebagai suatu strategi perusahaan yang dapat memacu dan menstabilkan pertumbuhan usaha secara jangka panjang. Oleh karena itu penting untuk mengungkapkan CSR dalam perusahaan sebagai wujud pelaporan tanggung jawab sosial kepada masyarakat

\section{H-3. Corporate Social Responsibility (CSR) berpengaruh positif terhadap Nilai Perusahaan}

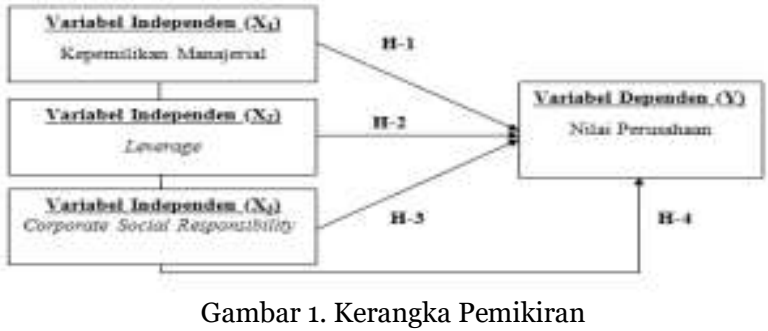

\section{METODE PENELITIAN}

\section{Sample Data}

Berdasarkan data terdapat 197 perusahaan bidang jasa yang terdaftar di Bursa Efek Indonesia pada tahun 20142018. Dari 197 perusahaan. yang dijadikan sampel pada penelitian adalah 13 perusahaan dengan jangka waktu 5 tahun. . Metode pengambilan data dengan sampling, Data yang diteliti bersumber dari laporan keuangan perusahaan yang terdaftar di Bursa Efek Indonesia. Sebagai variable independen adalah : Kepemilikan Manajerial,Leverage dan Corporate Social Responsibility sedang variable Dependent : Nilai Perusahaan (BPV).

\section{Varible Operasional}

Adanya kepemilikan saham oleh manajemen , maka manajer akan lebih berhati-hati dalam bertindak karena manajer juga menanggung risiko atas keputusan yang diambilnya. Hal tersebut dapat mengurangi konflik kepentingan yang tejadi antara pemegang saham dan manajer dan memungkinkan manajer lebih termotivasi demi meningkatkan kinerjanya dalam menjalankan dan mengelola perusahaan kemudian akan meningkatkan nilai perusahaan.Kepemilikan manajerial merupakan hasil persentase seluruh saham yang dimiliki oleh manajer, direksi, serta 
dewan komisaris dari seluruh jumlah modal saham yang beredar.

\section{Rasio leverage}

Rasio leverage adalah untuk melihat seberapa besar aktiva dibiayai oleh utang perusahaan. Dari hasil pengukuran, apabila memiliki nilai rasio yang tinggi artinya pendanaan dengan utang semakin banyak, hal tersebut akan menyebabkan perusahaan sulit mendapatakan pinjaman karena dikhawatirkan perusahaan tidak dapat mengembalikannya.

\section{Corporate Social Responsibility}

diukur dengan cara setiap item
pengungkapan CSR dalam instrumen penelitian ini diberi nilai 1 jika diungkapkan dan nilai o jika tidak diungkapkan. Instrumen yang akan digunakan dalam penelitian ini mengacu pada instrumen yang dibuat oleh GRI (Global Reporting Intiative) yang diperoleh dari website GRI www.globalreporting.org

Pada penelitian ini, nilai perusahaan diukur dengan rasio Tobin's Q. Rasio ini dinilai dapat memberikan informasi terbaik, karena dalam rasio Tobin's Q memasukan semua unsur utang dan modal saham perusahaan, Serta seluruh aset perusahaan. Dalam penelitian ini rasio Tobin's Q dihitung dengan menggunakan rumus yang dikembangkan oleh Chung dan Pruitt, seperti dalam penelitian Rahmah, (2016).

\section{HASIL PENELITIAN DAN PEMBAHASAN}

\section{Statistik Deskriptif}

Dalam penelitian ini statistik deskriptif memberikan gambaran atau deskripsi data yang dilihat dari nilai minimum, nilai maksimum, nilai rataratadan standar deviasi. Hasil analisis data variabel independen yang digunakan dalam penelitian ini dari pengumpulan data dan telah dilakukan pengolahan data adalah sebagai berikut:

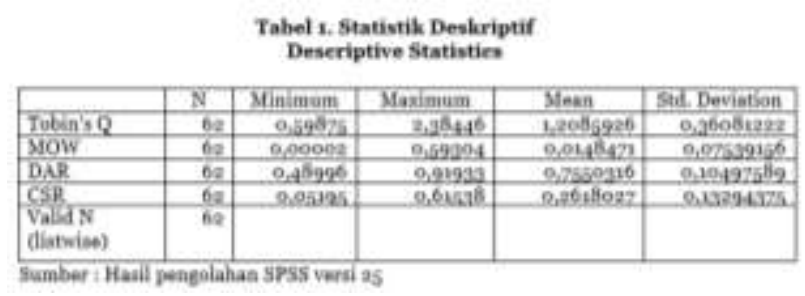

Berdasarkan tabel 1 di atas, maka diperoleh hasil sebagai berikut:

1. Nilai perusahaan dilihat dengan Tobin's Q.,dari tiga belas sampel pada perusahaan jasa memiliki nilai minimum sebesar 0,59875, nilai maksimum sebesar 2,3446 , rata-rata sebesar 1,2085926 , dan standar deviasi sebesar 0,36081222.

2. Nilai rata-rata lebih besar dari nilai standar deviasi yaitu 1,2085926 > 0,36081222 memiliki arti bahwa nilai perusahaan (Tobin's Q) baik.

3. Kepemilikan Manajerial (MOW) dari tiga belas sampel perusahaan jasa memiliki nilai minimum sebesar 0,00002, nilai maksimum sebesar 0,59304, nilai ratarata sebsar 0,0148471, dan nilai standar deviasi sebesar 0,07539156. Nilai ratarata lebih kecil dari standar deviasi yaitu o,0148471 < o,07539156 memiliki arti bahwa kepemilikan manajerial (MOW) kurang baik. Leverage (Utang) dapat dilihat dari DAR yang diukur dengan Debt to Total Asset Ratio dari tiga belas sampel perusahaan jasa memiliki nilai minimum sebesar 0,48996, nilai maksimum sebesar 0,91933, nilai ratarata sebesar 0,7550316, dan nilai standar deviasi sebesar 0,10497589. Nilai ratarata lebih besar dari standar deviasi yaitu 
$0,7550316>0,10497589$ memiliki arti bahwa sebaran nilai leverage atau DAR adalah baik. Corporate Social Responsibility dari tiga belas sampel perusahaan jasa memiliki nilai minimum sebesar 0,05195, nilai maksimum sebesar 0,61538 , nilai rata-rata 0,2618027 , dan nilai standar deviasi sebesar 0,13294375. Nilai rata-rata lebih besar dari nilai standar deviasi yaitu 0,2618027 > 0,13294375 memiliki arti bahwa sebaran nilai corporate social responsibility cukup baik.

\section{Uji Asumsi Klasik}

Uji asumsi klasik digunakan untuk mendapatkan model regresi yang baik, terbebas dari penyimpangan. Uji asumsi klasik terdiri dari uji normalitas, uji multikolinearitas, uji heteroskedastisitas, serta uji autokorelasi

Tabel 2. Hasil Uji Normalitas One-Sample Kolmogorov-Smirnov Test

\begin{tabular}{|l|l|r|}
\hline \multicolumn{2}{|l|}{} & \multicolumn{2}{|c|}{$\begin{array}{l}\text { Rnstandardized } \\
\text { Residual }\end{array}$} \\
\hline $\mathrm{N}$ & Mean & $-0,0028$ \\
\hline \multirow{2}{*}{$\begin{array}{l}\text { Normal } \\
\text { Parameters }\end{array}$} & $\begin{array}{l}\text { Std. } \\
\text { Deviation }\end{array}$ & 0,26773 \\
\hline & & 0,105 \\
\hline $\begin{array}{l}\text { Most Extreme } \\
\text { Differences }\end{array}$ & Absolute & 0,105 \\
\cline { 2 - 3 } & Positive & $-0,067$ \\
\cline { 2 - 3 } & Negative & 0,105 \\
\hline Test Statistic &, $084^{\mathrm{c}}$ \\
\hline Asymp. Sig. (2-tailed) & \\
\hline a. Test distribution is Normal. \\
\hline \multicolumn{2}{|l}{ b. Calculated from data. } \\
\hline
\end{tabular}

Sumber : Hasil Pengolahan SPSS Versi 25

Berdasarkan hasil tabel.1 Uji Normalitas atau one sampel KolmogorofSmirnof test dapat diketahui bahwa nilai signifikansi (Asymp. Sig.2-tailed) pada variabel Kepemilikan Manajerial (MOW), variabel leverage yang dihitung dengan debt to asset ratio (DAR), variabel corporate social responsibility (CSR), dan variabel nilai perusahaan (Tobin's Q) dengan hasil signifikansi 0,084 karena hasil signifikan lebih dari 0,05 maka residual berdistribusi normal.

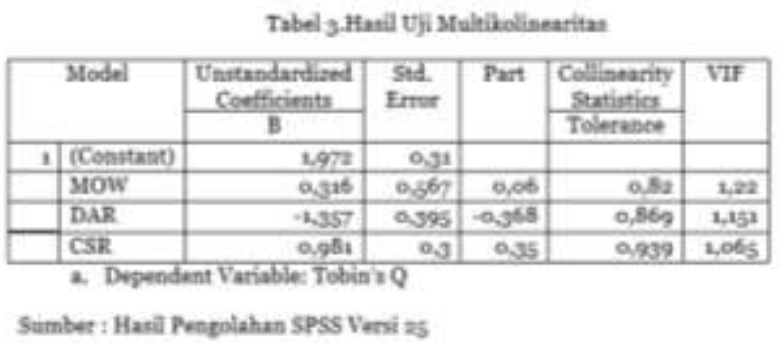

Berdasarkan hasil tabel 2. Uji Multikolinearitas dapat diketahui bahwa nilai tolerance lebih dari 0,10 dan nilai VIF kurang dari 10 maka dapat disimpulkan bahwa model regresi tidak terjadi masalah multikolinearitas.

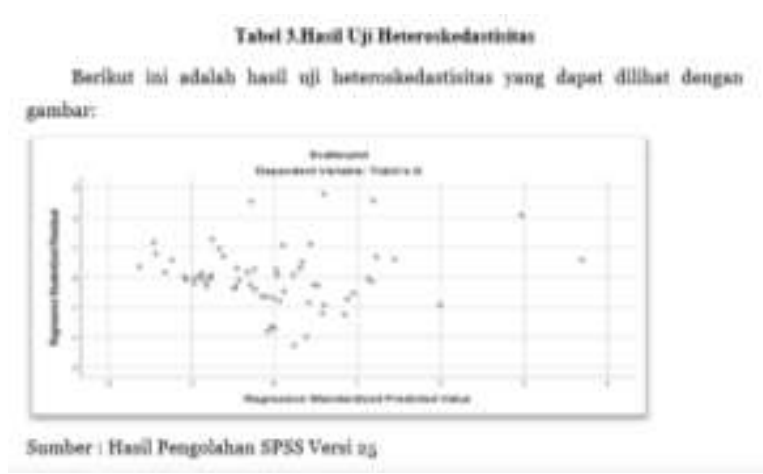

Berdasarkan Tabel.3 Uji Heteroskedastisitas menampilkan grafik scatterplot dari variabel dependen yaitu Nilai Perusahaan. Dari grafik tersebut dapat diketahui bahwa titik-titk menyebar dengan pola yang tidak jelas di atas dan di bawah angka o (nol) pada sumbu Y. Jadi dapat disimpulkan bahwa tidak terjadi masalah heteroskedastisitas pada model regresi.

Diperoleh nilai DL sebesar 1,4896 dan nilai DU sebesar 1,6918 karena o kurang dari nilai DW sebesar 2,006 dan DL lebih besar dari DW. Dengan ini maka di dapat 4$\mathrm{du}=2,3082$. Maka dapat diketahui 
du $<$ dw $<4$-du dengan hasil $1,6198<2,006<2,3082$ sehingga dapat disimpulkan bahwa model regresi yang digunakan dalam penelitian ini terbebas dari masalah autokorelasi atau tidak terjadi autokorelasi.

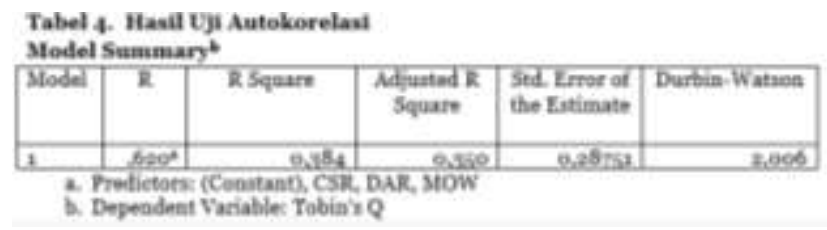

Dari hasil tabel di atas dapat dinyatakan dengan persamaan sebagai berikut:

$$
\mathrm{Y}=\mathrm{a}_{\mathrm{a}}+\mathrm{X}_{1}+\mathrm{X}_{2}+\mathrm{X}_{3}+\ldots+\mathrm{e}
$$

Tobin's Q $=1,972+0,316 \mathrm{MOW}-1,357 \mathrm{DAR}$ $+0,981$ CSR

Keterangan :

Tobin's Q = Nilai Perusahaan

a $\quad=$ Konstanta

MOW = Kepemilikan Manajerial

$\mathrm{DAR}=$ Leverage

CSR = Corporate Social Responsibility

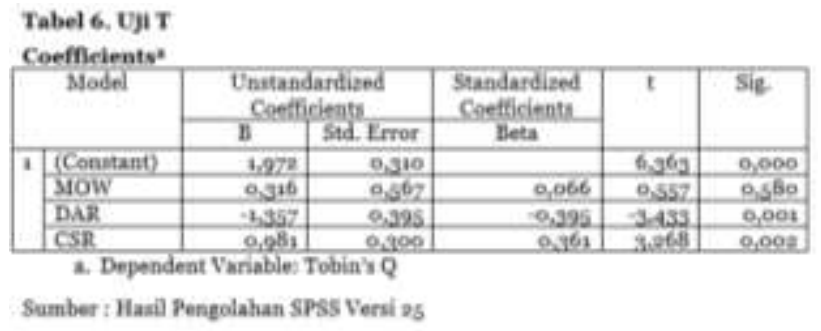

\section{PEMBAHASAN}

\section{Pengaruh Kepemilikan Manajerial terhadap Nilai Perusahaan}

Berdasarkan hasil uji koefisien regresi, kepemilikan manajerial (MOW) tidak berpengaruh secara signifikan terhadap nilai perusahaan. Hal ini dapat dilihat dari nilai signifikan sebesar 0,580 , nilai siginifikan ini lebih besar dari tingkat alpha (o,05. Penelitian ini didikung oleh,(Purnamasari, 2017) bahwa kepemilikan manajerial tidak berpengaruh terhadap nilai perusahaan karena belum banyak pihak manajer yang memiliki saham perusahaan dengan jumlah yang cukup signifikan. Ketika kepemilikan manajerial rendah maka insentif terhadap kemungkinan terjadinya perilaku oportunistik manajer akan meningkat..

Hasil penelitian ini tidak sejalan dengan agency theory, yang menyatakan untuk mengurangi agency cost, dengan jumlah yang cukup signifikan. Ketika kepemilikan manajerial rendah maka insentif terhadap kemungkinan terjadinya perilaku oportunistik manajer akan meningkat,Hasil penelitian ini bertolak belakang dengan Puspanngrum (2017) yang menyatakan bahwa kepemilikan manajerial berpengaruh positif dan tidak signifikan terhadap nilai perusahaan. Penelitian Soflamira dan Asandimitra (2017), Sudarma dan Damayanti (2017) menyatakan bahwa kepemilikan manajerial berpengaruh positif dan signifikan terhadap nilai perusahaan.

\section{Pengaruh Leverage terhadap Nilai Perusahaan}

Berdasarkan hasil uji koefisien regresi leverage (DAR) berpengaruh negatif dan signifikan terhadap nilai perusahaan. Hal ini dapat dilihat dari nilai signifikan 0,002, nilai signifikan ini lebih kecil dari tingkat alpha (0,05). Semakin tinggi jumlah pendanaan yang berasal dari utang pihak ketiga, maka akan mengakibatkan menambahnya beban bunga yang harus dibayar oleh perusahaan.

Hasil penelitian ini sejalan dengan penelitian yang dilakukan oleh Solfamira dan Asandimitra (2017) yang menyatakan bahwa leverage berpengaruh negatif 
signifikan terhadap nilai perusahaan dan menurut peneliti,(Suwardika \& Mustanda, 2017) bahwa Berdasarkan hasil penelitian tersebut menunjukkan bahwa semakin tinggi nilai leverage maka nilai perusahaan juga akan semakin meningkat.

Hasil pengujian senada dengan teori yang dikemukakan Modigliani dan Miller (1963) yang mengungkapkan bahwa apabila perusahaan dikenakan pajak penghasilan maka penggunaan hutang merupakan keputusan yang tepat diambil oleh perusahaan untuk meningkatkan nilai perusahaan, Selain itu, penelitian ini bertolak belakang dengan penelitian Mareta dan Yanti (2019) yang menyatakan bahwa leverage tidak berpengaruh terhadap nilai perusahaan.

\section{Pengaruh Corporate Social Responsibility terhadap Nilai Perusahaan}

Berdasarkan hasil uji koefisien regresi, corporate social responsibility (CSR) berpengaruh positif dan signifikan terhadap nilai perusahaan. Hal ini dapat dilihat dari nilai signifikan 0,001 , nilai signifikan ini lebih kecil dari tingkat alpha $(0,05)$. Hasil penelitian ini sejalan dengan penelitian yang dilakukan oleh Puspaningrum (2017) yang menyatakan bahwa CSR berpengaruh positif terhadap nilai perusahaan serta oleh,(Embang, 2016) yang menyatakan CSR memiliki pengaruh positif signifikan terhadap nilai perusahaan. yang artinya bahwa para investor di Indonesia telah mempertimbangkan laporan tanggung jawab sosial perusahaan sehingga kebutuhan akan informasi tanggung jawab sosial merupakan salah satu bahan pertimbangan dalam pengambilan keputusan investasmempertimbangkan laporan tanggung jawab sosial perusahaan sehingga kebutuhan akan informasi tanggung jawab sosial merupakan salah satu bahan pertimbangan dalam pengambilan keputusan investasi.

Hal Selain itu penelitian ini bertolak belakang dengan pebelitian yang dilakukan oleh Sudarma dan Darmayanti (2017) yang menyatakan bahwa CSR memiliki pengaruh negatif namun tidak signifikan terhadap nilai perusahaan. Penelitian Rahmah (2016) menyatakan bahwa CSR tidak berpengaruh signifikan terhadap nilai perusahaan.

\section{KESIMPULAN}

Berdasarkan hasil penelitian, maka diperoleh kesimpulan sebagai berikut : Secara parsial ,kepemilikan manajerial tidak berpengaruh secara signifikan terhadap nilai perusahaan ini disebabkan karena Manajemen lebih banyak dikendalikan pemilik mayoritas sehingga manajemen hanya sebagai kepanjangan tangan pemilik mayoritas dan rendahnya kepemilikan manajerial mengakibatkan manajerial cenderung mementingkan kepentingan pribadi, bukan berdasarkan pada maksimalisasi nilai dalam pengambilan keputusan keuangan perusahaan, sehingga sering terjadi pertentangan kepentingan antara manajerial dan pemegang saham. Kondisi ini merupakan konsekuensi dari pemisahan fungsi pengelolaan dengan fungsi kepemilikan. leverage berpengaruh negatif dan signifikan terhadap nilai perusahaan karena Penggunaan hutang yang tinggi akan menyebabkan timbulnya biaya kebangkrutan, biaya keagenan, beban bunga yang semakin besar dan sebagainya. Apabila biaya kebangkrutan semakin besar, tingkat keuntungan yang disyaratkan oleh pemegang saham juga semakin tinggi. Biaya modal hutang juga akan semakin tinggi karena pemberi pinjaman akan membebankan bunga yang tinggi sebagai 
kompensasi kenaikan risiko kebangkrutan corporate social responsibility berpengaruh positif dan signifikan terhadap nilai perusahaan, sedangkan secara bersama-sama, kepemilikan manajerial, leverage, dan corporate social responsibility berpengaruh positif dan signifikan terhadap nilai perusahaan karena semakin luas pengungkapan pertanggungjawaban sosial perusahaan maka nilai perusahaan juga akan semakin meningkat. Tingginya nilai perusahaan menyebabkan keberadaan perusahaan tersebut akan lebih disorot oleh stakeholder-nya, apabila perusahaan dapat memaksimalkan manfaat yang diterima stakeholder maka akan timbul kepuasan bagi stakeholder yang akan meningkatkan nilai perusahaan selain itu pengungkapan Corporate Social Responsibility dalam laporan tahunan (annual report) memperkuat citra perusahaan.

\section{SARAN}

Adapun saran-saran yang diberikan melalui penelitian ini adalah sebagai berikut: Penelitian selanjutnya diharapkan dapat menggunakan periode penelitian yang lebih panjang agar mendapatkan hasil yang lebih baik. Bagi para investor dan pemegang saham perusahaan yang terdaftar di BEI agar lebih memperhatikan aspek pengungkapan CSR suatu perusahaan sebagai pertimbangan dalam melakukan investasi, serta bagi perusahaan nantinya agar mampu melaksanakan prinsip CSR secara konsisten dan meningkatkan pengungkapan CSR dengan cara melakukan pengungkapan CSR pada laporan tahunan, sehingga diharapkan akan dapat menghasilkan kepercayaan respon yang positif baik bagi investor maupun publik sehingga mampu meningkatkan nilai perusahaan.

\section{DAFTAR PUSTAKA}

Fahmi, I. (2015). Pengantar Manajemen Keuangan. Bandung : Alfabeta.

Fauziah, F. (2017). Kesehatan Bank, Kebijakan Deviden, dan Nilai Perusahaan Teori dan Kajian Empiris, Samarinda : RV Pustaka Horizon.

Christiani, L., \& Herawaty, V. (2019). Pengaruh Kepemilikan Manajerial, Komite Audit, Leverage, Profitabilitas, Dan Ukuran Perusahaan Terhadap Nilai Perusahaan Dengan Manajemen Laba Sebagai Variabel Moderasi. Prosiding Seminar Nasional Cendekiawan, 2. https://doi.org/10.25105/semnas.voio .5824

Embang, E. L. (2016). Pengaruh CSR Dan GCG Terhadap Nilai Perusahaan Sektor Manufaktur Yang Terdaftar di BEI 201002014. Jurnal Parsimonia, 2(3), 54-67.

Fajriana, A., \& Priantinah, D. (2016). Pengaruh Corporate Social Responsibility, Keputusan Investasi, Dan Struktur Modal Terhadap Nilai Perusahaan. Nominal, Barometer Riset Akuntansi Dan Manajemen, 5(2), 16-28. https://doi.org/10.21831/nominal.v5i2 .11721

Hidayat, W. W. (2018). Pengaruh

Profitabilitas , Leverage Dan Pertumbuhan Penjualan Terhadap Penghindaran Pajak : Studi Kasus. Jurnal Riset Manajemen Dan Bisnis (JRMB) Fakultas Ekonomi UNIAT, 3(1), 19-26.

Kusumayanti, N., \& Astika, I. (2016). Corporate Social Responsibility Sebagai Pemediasi Pengaruh Ukuran Perusahaan, Profitabilitas Dan Leverage Pada Nilai Perusahaan. EJurnal Akuntansi (Vol. 15). 
Mareta, S dan Yanti, I. S. (2019). The Influence of Liquidity, Leverage, and Profitability on Company Value (Empirical Study on Basic Industry and Chemical Companies Listed on Indonesia Stock Exchange), 5 (7), 194198.

Nurhayati, I., Poerwati, T., \& Kartika, A. (2019). Dampak Moderasi Profitabilitas Dan Leverage Terhadap Pengaruh Csr Pada Nilai Perusahaan Di Indonesia. Prosiding SENDI_U, 3(1), 978-979.

Pracihara, S. M. (2016). Pengaruh Kebijakan Hutang, Kepemilikan Manajerial, Kebijakan Dividen, Dan Ukuran Perusahaan Terhadap Nilai Perusahaan (Studi Pada Sektor Pertambangan Yang Terdaftar Di Bei Periode 2011-2014). Jurnal Ilmu Manajemen (JIM), 4(2).

Prasetyorini, B. F. (2013). Pengaruh Ukuran Perusahaan, Leverage, Price Earning Ratio dan Profitabilitas terhadap Nilai Perusahaan. Jurnal Ilmu Manajemen (JIM), 1(1), 10-26.

Puspaningrum, Y. (2017). Pengaruh Corporate Social Responsibility dan Kepemilikan Manajerial terhadap Nilai Perusahaan dengan Profitabilitas dan Ukuran Perusahaan sebagai Variabel Moderating, (2), 1-14.

Purnamasari, I. C. (2017). Corporate Social

Responsibility, Kepemilikan

Institusional , Dan Kepemilikan

Manajerial Terhadap Nilai

Perusahaan. Jurnal Ilmu Dan Riset

Manajemen, 6(2), 1-16.

Rahmah, N. (2016). Pengaruh Corporate Social Responsibility dan Kinerja Keuangan terhadap Nilai Perusahaan, 7-62.

Suwardika, I., \& Mustanda, I. (2017). Pengaruh Leverage, Ukuran Perusahaan, Pertumbuhan
Perusahaan, Dan Profitabilitas

Terhadap Nilai Perusahaan Pada

Perusahaan Properti. E-Jurnal

Manajemen UNUD, 6(3), 254488.

Soflamira, N. A dan Asandimitra, N. (2017).

Capital Expenditure, Leverage, Good Corporate Governance, Corporate Social Responsibility : Pengaruhnya terhadap Nilai Perusahaan, 20 (2), 191-214.

Subagyo, et al. (2018). Akuntansi Manajemen Berbasis Desain, Yogyakarta : Gajah Mada University Press.

Sudarma, I. K. dan Darmayanti, N. P. (2017). Pengaruh CSR, Kepemilikan Manajerial, dan Profitabilitas terhadap Nilai Perusahaan Sektor Pertambangan pada Indeks Kompas 10o, 6 (4), 1906-1932.

Triyono, F., \& Setyadi, E. D. I. J. (2015). Pengaruh Good Corporate Governance, Dan Pengungkapan Corporate Social Responsibility Terhadap Nilai Perusahan (Pada Perusahaan Property and Real Estate Yang Terdaftar Di Bei). Jurnal Kompartemen, 13(1), 64-82.

Widyaningsih, D. (2018). Kepemilikan Manajerial, Kepemilikan Institusional, Komisaris Independen, serta Komite Audit pada Nilai Perusahaan dengan Pengungkapan CSR sebagai Variabel Moderating dan Firm Size sebagai Variabel Kontrol, 19 (01), 38-52.

Widhaningayu, E. (2017). Pengaruh Kepemilikan

Institusional,Pengungkapaan CSR ,laba,Nilai buku dan Ukuran perusahaan terhadap Nilai Perusahaan. Jurna Ekonomi Akuntansi Dan Manajemen (JEAM), 12(2), 21-44. 